\title{
A Commentary on the African Commission's General Comment on the Right to Freedom of Movement and Residence under Article 12(1) of the African Charter on Human and Peoples' Rights
}

\author{
Romola Adeola* \\ University of Pretoria, South Africa \\ romola.adeola@gmail.com \\ Frans Viljoen** \\ University of Pretoria, South Africa \\ frans.viljoen@up.ac.za \\ Trésor Makunya Muhindo*** \\ University of Pretoria, South Africa \\ tresormakunyamuhindo@gmail.com
}

\begin{abstract}
In 2019, the African Commission on Human and Peoples' Rights adopted General Comment No 5 on the African Charter on Human and Peoples' Rights: The Right to Freedom of Movement and Residence (Article 12(1)). In this general comment, the commission elaborated on the right to freedom of movement and residence within state borders. This issue, while explicit in international human rights law, is a challenge within various jurisdictions, including in Africa. This article provides a background to and commentary on General Comment No 5, leveraging on the insight of the authors, who participated in its drafting. Unlike the UN Human Rights Committee's earlier general comment, General Comment No 5 provides detailed guidance on the internal dimension of the right to free movement and residence. As "soft law", its persuasive force depends on a number of factors, including its use at the domestic level, its visibility and its integration into regional human rights jurisprudence.
\end{abstract}

\section{Keywords}

The right to freedom of movement and residence, African Charter, article 12, African Commission on Human and Peoples' Rights, general comment, Africa

\footnotetext{
Coordinator, Global Engagement Network on Internal Displacement in Africa; fellow, Centre for Human Rights, Faculty of Law, University of Pretoria.

** Director, Centre for Human Rights, Faculty of Law, University of Pretoria.

*** Doctoral candidate, Centre for Human Rights, Faculty of Law, University of Pretoria.
} 


\section{INTRODUCTION}

The right to freedom of movement and residence is vital to furthering human development. ${ }^{1}$ Mobility is intimately intertwined with the exercise of human autonomy and is integral to the well-being of individuals and groups. Article 12 of the African Charter on Human and Peoples' Rights (African Charter) ${ }^{2}$ embodies this right in its composite construction. It captures the various dimensions of movement: exit out of a country, entry into a country and movement within the borders of a state. In recent years, there has been a regional drive towards free movement of persons as an imperative for economic integration. ${ }^{3}$ Given that creating pathways for ease of movement across national territories is required in developing national economic potential, there has been an increase in the relaxation of regulations in order to facilitate movement across borders.

While article 12(2)-(5) of the African Charter deals with other aspects of mobility across state borders, and between states, ${ }^{4}$ article $12(1)$ expresses one of the specific dimensions captured in article 12: movement and residence within the borders of a state. ${ }^{5}$ It reads: "[e]very individual shall have the right to freedom of movement and residence within the borders of a State provided he abides by the law". In 2019, the African Commission on Human and Peoples' Rights (African Commission) adopted a general comment to provide guidance on the content of state obligations under article 12(1): General Comment No 5 on the African Charter on Human and Peoples' Rights: The Right to Freedom of Movement and Residence (Article 12(1)) (General Comment No 5). ${ }^{6}$

1 J Klugman Overcoming Barriers: Human Mobility and Development (UN Development Programme, Human Development Report 2009, Palgrave Macmillan), available at: <https://www.preventionweb.net/files/11269_HDR2009ENComplete1.pdf> (last accessed 2 January 2021).

2 African Charter on Human and Peoples' Rights (1981).

3 Protocol on Free Movement of Persons, Right of Residence and Right of Establishment in Africa, adopted by the African Union Heads of State and Government, 30th ordinary session, Addis Ababa, Ethiopia, January 2018.

4 These sub-arts provide: “(2) Every individual shall have the right to leave any country including his own, and to return to his country. This right may only be subject to restrictions, provided for by law for the protection of national security, law and order, public health or morality. (3) Every individual shall have the right, when persecuted, to seek and obtain asylum in other countries in accordance with the law of those countries and international conventions. (4) A non-national legally admitted in a territory of a State Party to the present Charter, may only be expelled from it by virtue of a decision taken in accordance with the law. (5) The mass expulsion of non-nationals shall be prohibited. Mass expulsion shall be that which is aimed at national, racial, ethnic or religious groups."

$5 \quad$ F Ouguergouz The African Charter on Human and Peoples' Rights: A Comprehensive Agenda for Human Dignity and Sustainable Democracy in Africa (2003, Kluwer Law International) at 121.

6 The full document is available at: <https://www.achpr.org/legalinstruments/detail?id= 74> (last accessed 2 January 2021). For an academic commentary on the issues emerging 
This article aims to provide a background to and commentary on General Comment No 5. As General Comment No 5 deals with article 12(1) of the African Charter, this article limits its focus to movement within the borders of the state. The article is divided into five substantive parts. First, it reflects on the importance of the right to free movement and residence in African history, highlighting issues that explain the need to pay attention to this right within the region. The article then establishes the rationale for the adoption of General Comment No 5. The next part examines the drafting history of General Comment No 5, giving background information on the development process. The article then provides a commentary on the provisions of General Comment No 5, reinforcing pertinent issues and subject areas covered in the general comment. Finally, the article focuses on the soft law nature of General Comment No 5, highlighting that its impact will be a matter of moral and political persuasion rather than binding legal authority. Overall, the article aims to provide insight into the content of the right to free movement and residence in the furtherance of the effective implementation of the African Charter as a whole.

\section{THE IMPORTANCE OF FREE MOVEMENT AND RESIDENCE IN AFRICA}

Mobility is part of human history. The fact that people move has been an integral part of human development across various epochs of African history, in pre-colonial, colonial and post-colonial Africa.

In pre-colonial times (predating the notion of the nation state and rigid boundaries), free movement was largely taken for granted. Before the emergence of the nation state, the governance structures in Africa, such as kingdoms, empires, chiefdoms and other polities, mostly operated at a limited geographic scale. Within each settled community, variable systems determined who would be part of, and allowed to settle within, a polity. Some traditional practices had a far-reaching impact on movement and residence, such as the practice of widows being expelled by the husband's family, losing their property in the process. ${ }^{7}$

Movements in the colonial state were patterned along economic opportunities under colonial rule. ${ }^{8}$ Under the erstwhile apartheid regime in South Africa, movements were racialized and restricted for political reasons. Restrictions on movement and residence were at the core of a process of social

contd

from General Comment No 5, see generally C Beyani Human Rights Standards and The Free Movement of People Within States (2000, Oxford University Press).

7 E Uchechukwu "Post-colonialism, gender, customary injustice: Widows in African societies" (May 2002) 24/2 Human Rights Quarterly 424.

8 For further discussion, see R Adeola "The African Union Protocol on Free Movement of Persons in Africa: Development, provisions and implementation challenges" (2019) 3 African Human Rights Yearbook 260. 
engineering aimed at the mass relocation of South Africa's black population away from "white" areas. Apartheid South Africa pass-laws required "black" South Africans to have authorisation to be within particular ("white") areas. In an attempt to enforce geospatial apartheid, under a system of migrant labour men were required to perform arduous labour within burgeoning industries and mines, while women and children were left behind in "reserves" or "homelands". The Blacks (Abolition of Passes and Co-ordination of Documents) Act No 67 of 1952 (Pass Laws Act) consolidated various pass laws into one nationwide pass law, which made it compulsory for all black South Africans over the age of 16 to carry a "passbook" at all times within white areas. The law stipulated where, when, and for how long a person could remain in "white" areas. Indian people were also not allowed to enter one of the four provinces, the Orange Free State. Political opponents were singled out for particular forms of restrictions on their movement. Fearful of the influence of the magnetic personality of Winnie Mandela, the apartheid government sought to silence her voice and render her invisible by imposing banning orders restricting her movement, initially to her home of Orlando West, Soweto and later, from 1977 to 1986, restricting her to the far-away dusty town of Brandfort. ${ }^{9}$

The solidifying of the nation state, the hallmark of the post-colonial epoch, saw families and communities ruptured by artificial boundaries and constrained in their movement and in their ability to retain their connectedness. ${ }^{10}$ Nomadic groups, such as the Amazigh in the Sahara and Sahel areas, were inhibited in their movement between and within states due to boundaries that did not correlate to their patterns of migration.

In most of Africa, the nation state was an imposition rather than the result of a protracted process of nation-building. Free movement within the newly forged and often fragmented state was therefore important to allow solidarity and common bonds to be cultivated. Intranational free movement makes manifest the democratic and political equality of all nationals. ${ }^{11}$ Regrettably, in several African countries, the independence period saw at least some continuity with the colonial-style repression of free movement that undermined full and equal political participation. A case decided in the immediate aftermath of Nigeria's independence in 1960 illustrates the kinds of issues that may and did arise. The facts of the case are as follows. Under a 1962 state of emergency declared in the then Western Region of Nigeria, the administrator of the region, Moses Majekodunmi, served an order restricting the movement

9 "Winnie Madikizela-Mandela" South African History Online, available at: <https://www. sahistory.org.za/people/winnie-madikizela-mandela> (last accessed 2 January 2021).

10 See E Allina-Pisano "Borderlands, boundaries, and the contours of colonial rule: African labor in Manica district, Mozambique, c. 1904-1908” (2003) 36/1 The International Journal of African Historical Studies 59 at 59-82.

11 A Hosein "Immigration and freedom of movement" (2013) 6 Ethics \& Global Politics 25 at 32-35. 
of Rotimi Williams (SAN), a prominent legal practitioner, to an area defined in the restriction order. The effect of the restriction was to prevent Williams from travelling to Lagos to argue a motion he had filed in a politically-charged matter. In its judgment on the matter, the Supreme Court of Nigeria held that every citizen of Nigeria was entitled to move freely throughout the Federation, and that the movement or residence of any person within Nigeria could be restricted only in the interest of defence, public safety, public order, public morality or public health. ${ }^{12}$ A further example is presented by the treatment of Ugandan opposition politician, Kizza Besigye, who had on numerous occasions experienced restrictions of his movement. ${ }^{13}$ Restrictions have also been imposed on the right to freedom of movement and residence of human rights defenders in Tunisia where, between 2014 and 2018, in the context of the "Arab Spring", at least 60 people were unlawfully prevented from travelling abroad or restricted in their travel within the country. ${ }^{14}$ Similarly, free movement and residence of internally displaced persons (IDPs), migrants and refugees within state borders have been infringed upon by several forms of restrictions, including through detention and confinement. One example is the policy of "encampment" of refugees, with severe restrictions on the possibility of free movement and settlement in the host country, instead of seeking durable solutions such as local integration. ${ }^{15}$ In 2020 , government restrictions aimed at curbing the spread of the novel coronavirus (COVID-19), imposed drastic measures such as curfews and restrictions on intra-state (interprovincial or inter-district) travel.

\section{THE NEED FOR NORMATIVE GUIDANCE ON THE RIGHT TO FREE MOVEMENT AND RESIDENCE IN AFRICA}

The need for normative guidance on the right to free movement and residence in Africa, which eventually found expression in General Comment No 5, arises from three main sources: the need for clarity on aspects of the wording of article 12(1) of the African Charter; the need to make sense of the relationship between article 12(1) and other relevant UN and African Union (AU) norms; and the need for a more harmonized approach to this issue among AU member states. General Comment No 5 itself refers to these motivations. ${ }^{16}$

\footnotetext{
12 RA Williams v MA Majekodunmi FSC 166/1962 (1 June 1962).

13 P Clottey "Uganda police restrict opposition leader's movement" (26 June 2013) Voice of America (Africa).

14 “Arbitrary restrictions on movement in Tunisia" (October 2018, Amnesty International).

15 See N Maple "Rights at risk: A thematic investigation into how states restrict the freedom of movement of refugees on the African continent" (New Issues in Refugee Research, research paper No 281, October 2016), available at: <https://www.refworld. org/pdfid/5857eb794.pdf> (last accessed 2 January 2021).

General Comment No 5, para 3.
} 
First, there is a need for clarity on the provisions of article 12(1) of the African Charter. ${ }^{17}$ A cursory glance at article 12(1) appears to reflect clarity from both normative and pragmatic perspectives. However, the reality on movement within state borders globally and in Africa indicates otherwise. Some of the elements of article 12(1) are quite vague. For instance, what is meant by "every individual"? ${ }^{18}$ The pertinence of this question arises from the position of constitutions across Africa, in which the right to freedom of movement and residence is often encased in a narrative of citizenship and nationality. ${ }^{19}$ Moreover, there is also the question of what is implied by freedom of movement and residence, especially given the difference in conceptual semantics in the English and French jurisdictions and also the fact that the notion of borders, while perhaps clear, is a source of tension in some parts of Africa. In the French text of the African Charter, the language adopted is "droit de circuler librement et de choisir sa residence"20 (literally, the right to move freely and choose one's residence), whereas the English text does not use verbs ("choose" and "move") or an adverb ("freely"), but relies on nouns ("freedom", "movement" and "residence"). ${ }^{21}$ Overall, there is the question of what it means to abide by "the law", which is in two parts. First, what law is contemplated: national law, international law or both? Secondly, what should constitute abiding by the law? Further, when might one be said to abide by the law? Put differently, what is the yardstick for conceptualizing abiding by the law? Even these questions do not capture the entire spectrum of complexities involved in the pragmatic implementation of this provision, particularly within contexts such as disasters and armed conflict. Indeed, these complexities account for the need for a general comment on article 12(1) of the African Charter.

A second rationale for General Comment No 5 is to relate article 12(1) of the African Charter to other relevant international human rights treaties of relevance to African states. At the global level, the origins of the codification of the right to free movement and residence within the human rights corpus date back to the 1948 Universal Declaration of Human Rights (UDHR). ${ }^{22}$

17 The African Court on Human and Peoples' Rights found, for the first time, the violation of art 12(1) of the African Charter but did not provide robust and comprehensive normative standards to assist states in preventing violations of the right to freedom of movement and residence. The court's decision in Lucien Ikili Rashidi $v$ United Republic of Tanzania, appln no 009/2005 (28 March 2019), paras 71-75 predates the adoption of General Comment No 5 by seven months.

18 African Charter, art 12(1).

19 See, for instance, the Constitution of Algeria (1989 amendments through 1996), art 55: "Any citizen enjoying his civil and political rights has the right to choose freely his place of dwelling and to move on the national territory"; Republic of Congo Constitution (2015), art 22: "Any citizen has the right to circulate freely on all the national territory".

20 See Charte Africaine des Droits de l'Homme et des Peuples (1981), art 12(1)

21 See African Charter, art 12(1).

22 See UDHR, art 13. 
While article 13(1) of the UDHR incorporates the general right of all persons to "freedom of movement and residence within the borders of each state", article 13(2) provides that all persons have "the right to leave any country, including [their] own, and to return to [their] country". Subsequently, the right to freedom of movement and residence has found expression in article 12 of the International Covenant on Civil and Political Rights (ICCPR), which guarantees the right to freedom of movement and movement. ${ }^{23}$ Since all but two African UN member states are party to the ICCPR, ${ }^{24}$ their obligations in respect of the intranational aspect of the right to movement and residence intersect with obligations they have under the African Charter. The Human Rights Committee adopted General Comment No 27 on article 12 of the ICCPR (General Comment No 27), which presents further guidance to states on free movement and residence in its composite form, including, to a limited extent, intranational movement. ${ }^{25}$ Predating the ICCPR, the 1951 UN Convention Relating to the Status of Refugees is also relevant, in so far as it provides for the right to freedom of movement and residence within the state of refuge. ${ }^{26}$

At the AU level, the protection provided under article 12(1) of the African Charter overlaps with the guarantees to IDPs under the AU Convention for the Protection and Assistance of Internally Displaced Persons in Africa (Kampala Convention). ${ }^{27}$ One of the most prominent dimensions of mobility within state borders is internal displacement. While there is an evident link between article 12(1) of the African Charter, which broadly relates to movements within state borders, and the Kampala Convention, the nature of their co-existence is not clarified. General Comment No 5 advances clarity in this regard by establishing a nexus between the Kampala Convention and the broader article 12(1) obligation. However, there is a point to be made about whether reading the obligations of the Kampala Convention into the African Charter raises new obligations for states that are not party to the Kampala Convention but are state parties to the African Charter. By 2020, the African Charter had been ratified by all AU member states, with the exception of Morocco, while only $31 \mathrm{AU}$ member states have ratified the Kampala Convention. In this regard, it is crucial to emphasize that the African Charter recognizes that the provisions of other instruments could serve as an inspiration for its interpretation. ${ }^{28}$ Under article 60 of the African Charter, the African Commission is allowed to "draw inspiration from other international law on human and peoples' rights, particularly from the provisions of various African instruments on human and peoples' rights". ${ }^{29}$ The

\footnotetext{
23 ICCPR (1966), art 12.

24 The exceptions are Comoros and South Sudan.

25 CCPR/C/21/Rev.1/Add.9, General Comment No 27.

261951 UN Convention Relating to the Status of Refugees, art 26.

27 Adopted at the special summit of the AU Heads of State and Government, Kampala, Uganda, 19-23 October 2009.

28 African Charter, arts 60 and 61.

29 Id, art 60.
} 
Kampala Convention is an important source in understanding the content of obligations in the context of internal displacement.

Thirdly, General Comment No 5 is needed to assist states in addressing challenges to the implementation of the right and to harmonize the "different understanding of their obligation toward realising this right". ${ }^{30}$ Most African constitutions contain the right to freedom of movement and residence in one form or another. ${ }^{31}$ The development of General Comment No 5 contributes to harmonizing differences among African states by providing benchmarks against which to assess whether their constitutional frameworks and practices are in line with international (human rights) law. Greater consistency is also desirable to guide the limitation of this right, which has largely been regulated unevenly under different African constitutions. If not carefully constructed, limitations can narrow the scope of the right to freedom of movement and the choice of residence, thereby generating varying standards on the continent.

\section{DRAFTING HISTORY OF GENERAL COMMENT NO 5}

Similar to previous general comments adopted by the African Commission, the drafting of General Comment No 5 proceeded through four phases: mandating, technical, consultative and formal acceptance. First, the African Commission officially mandated the process of evolution and adoption of a

30 General Comment No 5, para 3.

311996 Algeria Constitution, art 44; 2010 Angola Constitution, art 25; 1990 Benin Constitution, art 25; 1966 Botswana Constitution, sec 14; 1997 Burkina Faso Constitution, art 19; 2018 Burundi Constitution, arts 25 and 33; 1996 Cameroon Constitution, preamble; 1992 Cape Verde Constitution, art 50; 2016 Central African Republic Constitution, art 5; 1996 Chad Constitution, art 44; 2001 Comoros Constitution, art 7(3); 2015 Congo Constitution, art 22; 2006 Democratic Republic of Congo Constitution, art 30; 1992 Djibouti Constitution, art 14; 2013 Egypt Constitution, art 62; 1996 Equatorial Guinea Constitution, art 13(d); 1997 Eritrea Constitution, art 19(8)-(9); 1995 Ethiopia Constitution, art 32; 1991 Gabon Constitution, art 11; 1997 The Gambia Constitution, art 25(2)-(3); 1996 Ghana Constitution, art 21(g) and (2); 2010 Guinea Constitution, art 10; 1984 Guinea Bissau Constitution, art 34; 2016 Côte d'Ivoire Constitution, art 21; 2010 Kenya Constitution, sec 39; 1993 Lesotho Constitution, secs 4 and 7; 1986 Liberia Constitution, art 13; 2011 Libya Constitution, art 14; 2010 Madagascar Constitution, arts 10 and 12; 1994 Malawi Constitution, sec 39; 1992 Mali Constitution, art 5; 1991 Mauritania Constitution, art 10(1); 1968 Mauritius Constitution, art 15; 2011 Morocco Constitution, art 24(4); 1990 Mozambique Constitution, art 83; 1990 Namibia Constitution, art 21; 2010 Niger Constitution, art 32; 1999 Nigeria Constitution, art 41(1); 2003 Rwanda Constitution, art 26; 2015 Sahrawi Arab Democratic Republic Constitution, art 40; 1975 Saõ Tomé Constitution, art 32; 2001 Senegal Constitution, arts 8 and 14; 1993 Seychelles Constitution, art 25(1); 1996 Sierra Leone Constitution, sec 18(1); 2012 Somalia Constitution, art 21; 1996 South Africa Constitution, sec 21; 2011 South Sudan Transitional Constitution, sec 27; 2019 Sudan Constitution, sec 60; 2005 Swaziland Constitution, sec 26; 1977 Tanzania Constitution, sec 17; 1992 Togo Constitution, art 22; 2014 Tunisia Constitution, art 24(2); 2005 Uganda Constitution, sec 29; 1996 Zambia Constitution, sec 22(1); 2013 Zimbabwe Constitution, sec 66. 
new set of standards to complement the African Charter. During the technical phase, research was undertaken and an initial draft prepared to steer the process. During the consultative phase, a number of meetings and consultations were held, both to improve the quality of the draft and to ensure its greater legitimacy through an inclusive process involving various role players. Finally, the draft was submitted to the African Commission, for final consideration and adoption. The whole process lasted two years, and did not in all respects unfold chronologically, with the formal mandate only coming some time into the drafting process.

At its 63rd ordinary session held from 24 October to 13 November 2018 in Banjul, the African Commission formally mandated the drafting process of General Comment No 5 through a resolution. ${ }^{32}$ In this resolution, the commission identified the "negative effects that restrictions to article 12(1) can have on the realization of other human rights" as an important reason for adopting a general comment on this provision. The "need to draft a General Comment in order to make clear the content of article 12(1)" and to "clarify the obligations" on states was identified as the aim of the process.

The initiative towards the adoption of a general comment on intranational movement and residence developed within the framework of the European Union-funded Pan-African (PANAF) programme, "Consolidating civil society's role in facilitating the transition from human rights standards into human rights practice through Africa-wide interventions", executed by a consortium of partners including the Norwegian Refugee Council. ${ }^{33}$ The idea to have a general comment adopted on article 12(1) was part of the project goals in respect of which the Norwegian Refugee Council took the lead.

The process was guided by the Special Rapporteur on Refugees, Asylum Seekers, IDPs and Migrants in Africa. The Centre for Human Rights, Faculty of Law, University of Pretoria, responded to a call for interest through the PANAF programme, and was selected to lead the technical drafting team. ${ }^{34}$

32 Resolution on the Drafting of a General Comment on Article 12(1) of the African Charter on Human and Peoples' Rights, ACHPR/Res. 407 (LXIII) 2018, available at: <https://www. achpr.org/sessions/resolutions?id=427> (last accessed 2 January 2021).

33 J Gbenagnon "PANAF Project Steering Committee meeting" (Addis Ababa, Ethiopia, 24-25 May 2018), available at: <https://www.acdhrs.org/panaf-project/> (last accessed 2 January 2021).

34 The team of three experts from the Centre for Human Rights drafted the background paper on key constitutional, legal, judicial and political development on the right to freedom of movement and the choice of residence in Africa, which served as preparatory work for the first draft of General Comment No 5. The team of experts was tasked to present the draft general comment to an expert meeting with nine additional experts, and to gather comments, observations and suggestions, which contributed to the second draft. The role of the expert team extended to presenting the second draft to the African Commission in October 2018 (Banjul), working on comments and presenting the revised draft to the commissioners in May 2019. The expert team equally engaged with non-governmental organizations, and received and incorporated comments from states. The bilingual composition (French / English) of the expert team facilitated 
The drafting of General Comment No 5 began with the development of a background paper on free movement of persons. ${ }^{35}$ This background paper was developed over a two-month period in 2018. Its aim was to provide a contextual background to the subject, including a survey of the international human rights legal terrain and national provisions on the right to free movement and residence. The background paper further incorporated the issues for consideration in General Comment No 5 by identifying areas that had to be clarified in the general comment in view of its interpretative objective. The background paper further proposed a structure for General Comment No 5. However, there was a general understanding that the outline would be adjusted as the process went along. At the inception stage, it was proposed that General Comment No 5 incorporate six substantive issues after an introduction: the nature and scope of article 12(1); limitation; the nature of state obligation; specific groups, specifically, refugees, IDPs and migrant workers; responsibility for violation by non-state actors; and interpreting the right to freedom of movement broadly. The blend of ideas that precipitated this outline emerged from an understanding of previous general comments by the African Commission and the pertinent issues covered by these normative standards. Following the preparation of this background paper, a draft general comment was prepared.

An expert consultation meeting was subsequently held in Addis Ababa, Ethiopia, in October $2018 .{ }^{36}$ The aim of this meeting was to carry out a critical examination of General Comment No 5. The insights from this meeting were derived from the expertise of key stakeholders, regional experts and international agencies, including the International Committee of the Red Cross, with the latter providing insights particularly in relation to movement in armed conflict situations. Following the expert meeting, General Comment No 5 was further discussed at the non-governmental organisation forum

contd

discussions with the special rapporteur, Africa experts and relevant stakeholders who could only speak one of the languages. This prevented the distorted text that generally results when translation is outsourced.

35 "Background paper on the General Comment on article 12(1) of the African Charter on Human and Peoples' Rights" (2019) (copy on file with the authors).

36 The authors of this article prepared the draft general comment to be considered. A group of experts who had command of relevant legal and constitutional issues related to the right to freedom of movement and the choice of residence attended. Their expertise covered the following areas: international human rights in Africa; public international law; international humanitarian law; the protection of indigenous populations in Africa; AU institutional law; children's rights; and comparative constitutional law in Africa. They were drawn from institutions such as the Norwegian Refugee Council, International Commission of Jurists, the International Committee of the Red Cross (Addis Ababa), the African Commission and the Secretariat of the African Commission. This project was commissioned by the Norwegian Refugee Council and Pan-African Liaison Office to the AU. 
that preceded the African Commission session in October 2018 at Banjul, The Gambia, to gather further views of civil society. ${ }^{37}$

At a subsequent meeting of the African Commission commissioners in May 2019, at which the draft General Comment No 5 was presented, there was general consensus that the draft shed appropriate light on the issue of free movement and residence. Some discussion ensued as to whether General Comment No 5 should be restricted to article 12(1), with some commissioners strongly arguing that intra-state movement should not be separated from other forms of movement, and that the opportunity should be used to clarify the whole of article 12. However, there was an eventual appreciation that, although the various other sub-provisions of article 12 were interconnected, a focus on article 12(1) was still useful. It was further recommended that there should be consultation with the public at large and, as such, General Comment No 5 had to be publicized for inputs from states and other relevant stakeholders. The limited comments subsequently received dealt mostly with technical drafting issues and proposed that General Comment No 5 be extended to deal with statelessness. ${ }^{38}$ However, given that a process was at the time underway towards the adoption by the African Commission of soft law standards on statelessness, ${ }^{39}$ this issue was not included in General Comment No 5. Following this process, General Comment No 5 was further discussed by the African Commission and eventually adopted at its 65th ordinary session in November $2019 .{ }^{40}$ Having explained the drafting process, it is now relevant to examine each of the provisions of General Comment No 5 in more detail.

\section{COMMENTARY}

General Comment No 5 is divided into ten parts and 62 paragraphs, and starts with a preface from the Special Rapporteur on Refugees, Asylum Seekers, IDPs and Migrants in Africa. In outline, the ten parts are: objectives and scope; background; the elements of article 12(1) of the African Charter; limitations; state

37 See agenda for Panel 3: The Draft General Comment on the African Charter on Human and Peoples' Rights: The Right to Free Movement and Residence (Article 12(1)) (16:1518:00 hours), Forum on the Participation of NGOs in the 63rd ordinary session of the African Commission and 37th African Human Rights Book Fair, Banjul, the Gambia (20-22 October 2018).

38 Comments were received from the government of Malawi, the International Committee of the Red Cross and the Coalition la Société Civile Ivoirienne Contre l'Apatridie (copies on file with the authors).

39 See Draft Protocol to the African Charter on Human and Peoples' Rights on the Specific Aspects of the Right to a Nationality and the Eradication of Statelessness in Africa (September 2015, as adopted by the African Commission), available at: <https://www. achpr.org/public/Document/file/English/draft_citizenship_protocol_en_sept2015_achpr. pdf> (last accessed 2 January 2021).

40 Final communiqué of the 65th ordinary session of the African Commission, Banjul, The Gambia (21 October - 10 November 2019). 
obligation for actions by state actors; responsibility of states for actions by nonstate actors; specific categories; access to justice and remedies; interpreting the right to freedom of movement and residence broadly; and submission of periodic state reports under article 62 of the African Charter.

General Comment No 5 begins with its objective and scope, in order specifically to set out the parameters of its coverage: article 12(1). It underscores the fact that article 12(1) of the African Charter is vital to advancing other human rights, in particular the rights to freedom of association, family, education, work and liberty. A person's detention is, for example, at the same time a deprivation of liberty and a restriction to freedom of movement and residence. Such a derivation has the potential to impact negatively on all the rights mentioned above. While accepting that article 12(1) is part of and may be linked to article 12 more broadly, General Comment No 5 does not elaborate on the other dimensions of article 12.

The next section of General Comment No 5 presents the background, reflecting on the premise for its development within the procedures of the African Commission. ${ }^{41}$ The fact that the right to freedom of movement and residence is recognized in all African constitutions, but with actual discrepancies, highlights the need for a common standard.

Following this general overview, the next section of General Comment No 5 moves to the core terms in the textual formulation of article 12(1) of the African Charter: "every individual", "the right to freedom of movement", "[the right of freedom to choose] residence", "within the borders of a State" and "provided he abides by the law". ${ }^{42}$

The notion of "every individual" is interpreted broadly to include every person regardless of the legality of their status within the territory of a state. During the drafting process, the question was posed whether the language of the ICCPR should be followed. Article 12(1) of the ICCPR qualifies the individuals it conceptually covers by stating that it applies to "everyone lawfully within the territory of a State". ${ }^{33}$ However, the African Charter is silent on the legality of presence and it was considered important to make this distinction clear from the very start. As such, "every individual" is interpreted to include "those who are legally and irregularly in the state including nationals, permanent residents, internally displaced persons, asylum seekers, refugees, indigenous populations, holders of residence permits and undocumented migrants". ${ }^{44}$ With respect to the interpretation of the "right to freedom of movement", 45 it was important to reinforce the need for the protection of non-nationals, in part, given that some national constitutional provisions were specific in connecting the notion of free movement with citizenship.

41 General Comment No 5, paras 1-6.

42 Id, paras 7-13.

43 Emphasis added.

44 General Comment No 5, para 8.

45 Id, para 9. 
As such, General Comment No 5 explicitly provides that non-nationals, "unlawfully in the territory of a state", whose status is "regularized either by becoming a refugee, permanent resident, holder of a temporary residence permit or any other equivalent document, are entitled to move freely in the state and benefit from the protection of that state". ${ }^{46}$

Moreover, General Comment No 5 accentuates that the notion of free movement must be regarded as the "rule and restriction the exception". ${ }^{47}$ Given that there was a potential for free movement to be politicized, General Comment No 5 further emphasizes that there must be a review of legislation that empowers the executive arm of government to "confine (including through house arrests and travel ban) certain persons, such as members of opposition parties and human rights defenders". 48 "Legislation" in this context must be understood broadly also to include laws in the context of article 12(1) that may exist at various levels of governance, particularly in decentralized systems of government where sub-national level governance may also be implicated.

With respect to the "[the right of freedom to choose] residence", there was significant deference to the French text of the African Charter, which is the original text and which originally framed this point as "right of freedom to choose residence". ${ }^{49}$ In this regard, it was emphasized that the right of freedom to choose residence "encompasses the prerogative of individuals to freely choose and change their place of dwelling within a state"..$^{50}$ Explicitly, mandatory residence is prohibited "unless prescribed by law", 51 for instance in situations of criminal justice administration. With regard to the notion of "within the border of a state", the geographical corpus of this is described to include land territories but also "airspace and maritime zones over which a state exercises control". ${ }^{22}$ On the content of "provided he abides by the law", this was rephrased to be more gender sensitive and as such, the language "provided [every individual] abides by the law" 53 was used instead. "Law" in this context, however, is interpreted to include both national and international human rights law. ${ }^{54}$ In its jurisprudence, the African Commission emphasized that the use of the phrase "abide by the law" "does not allow national law to be interpreted in a way that conflicts with international human rights law". ${ }^{55}$

46 Ibid.

47 Id, para 10.

48 Id, para 9.

49 The French text of the African Charter, art 12(1) reads: "Toute personne a le droit de circuler librement et de choisir sa résidence à l'intérieur d'un Etat, sous réserve de se conformer aux règles édictées par la loi." See Charte Africaine des Droits de l'Homme et des Peuples (1981).

50 General Comment No 5, para 11.

51 Ibid.

52 Id, para 12.

53 Id, para 13.

54 Ibid.

55 Media Rights Agenda v Nigeria (2000) AHRLR 273 (ACHPR 2000), para 75. 
Since the rights in the African Charter are not absolute, there was a need to elaborate on limitations and examine the scope of the right to freedom of movement and residence within specific contexts, including disasters, development projects and armed conflict situations. ${ }^{56}$ While generally expressing that rights must not be rendered illusory, General Comment No 5 reinforces article 27(2) of the African Charter as the only permissible basis for the limitation of rights under the African Charter. In view of this provision, limitation of rights must be premised on "due regard to the rights of others, collective security, morality and common interest". ${ }^{57}$

With respect to disasters, the right to free movement of "persons at risk of serious and imminent threat may not be restricted, unless such restriction is provided by law and is absolutely necessary to respond to the threat to life, health or safety of affected populations". ${ }^{58}$ It is important to note that this section of General Comment No 5 is titled "disasters". While subsequent elaboration emphasizes natural disasters, the standards articulated here apply to disaster situations more generally (human and natural) in line with relevant international standards. ${ }^{59}$ In disaster situations, for instance, the right to free movement of persons may be limited for the preservation of life, health and safety. This limitation has been tested within the context of the novel coronavirus (COVID-19). Within the context of the International Law Commission definition, the COVID-19 situation may be regarded as a disaster given the fact that it is a "calamitous event ... resulting in widespread loss of life". ${ }^{60}$ Restrictions on freedom of movement amid COVID-19 affect some individuals disproportionately, ${ }^{61}$ and have sometimes been abused by governments as they aim to flatten the curve of infections through public health measures such as physical distancing, lockdowns, quarantine, curfews and border closures. While COVID-19 has been largely viewed as a reasonable ground for restricting rights, ${ }^{62}$ whether the specific measures adopted by governments were justified and rational has been contested. Courts have also tended to err on the side of caution. In the South African case of Ex Parte: van Heerden, for instance, the High Court displayed great deference in respect of an interstate travel ban based on the declared national state of disaster. ${ }^{63}$ In the Kenyan case of Ajuang and Oyugiv Osodo, the High Court ruled that, "it is better

56 General Comment No 5, paras 14-23.

57 African Charter, art 27(2).

58 General Comment No 5, para 18.

59 See International Law Commission "Draft articles on the protection of persons in the event of disasters" (2016).

60 Id, art 3.

61 In particular, women, migrant workers and children.

62 Joan Akoth Ajuang and Brian Thomas Oyugi $v$ Michael Owuor Osodo and Others [2020] eKL, available at: <http://kenyalaw.org/caselaw/cases/view/197002/> (last accessed 5 January 2021).

$63(1079 / 2020)$ [2020] ZAMPMBHC 5 (27 March 2020), available at: <http://www.saflii. org/za/cases/ZAMPMBHC/2020/5.html> (last accessed 2 January 2021). 
to err than to be sorry". ${ }^{64}$ While recognizing that free movement and residence of persons may be restricted on account of disasters, General Comment No 5 emphasizes that such measures must be absolutely necessary to respond to the threat and must not be "exercised indiscriminately". ${ }^{65}$ Evidently, what this suggests is the need for restrictions to cohere with the legitimate objective sought to be achieved, based on a careful assessment of a situation. ${ }^{66}$

In situations where the right to free movement and residence is sought to be limited by situations of development-induced displacement, it is crucial that "the free, prior and informed consent of affected populations is sought through an inclusive and non-discriminatory decision-making process". ${ }^{67}$ Article 10 of the Kampala Convention requires states to ensure that, in situations of development projects, feasible alternatives are considered, with persons likely to be displaced being fully informed and consulted on the process. ${ }^{68}$ The notion of consultation in development practice assumes various forms of meanings, sometimes as the weakest form of participation. However, through an understanding of the Kampala Convention and its emphasis on the prevention of arbitrary displacement as a right, there is a need to be guided by the imperative of realizing sustainable solutions. Achieving sustainable solutions requires that the consent of persons likely to be displaced is sought. Moreover, the Guiding Principles on Internal Displacement, from which the Kampala Convention draws normative strength, ${ }^{69}$ emphasize the importance of seeking free and informed consent. ${ }^{70}$ This further coheres with the notion of development as a tripod of sustainability (economic, social and environmental), as also reflected in articles 22 and 24 of the African Charter.

64 Above at note 62, para 267: "It follows that if the consequences of an activity could be serious and subject to scientific uncertainties ... then precautionary measures should be taken, or the activity should not be carried out."

65 General Comment No 5, para 15.

66 The African Commission published press statements to ensure that government measures to combat COVID-19 respect individuals' and peoples' rights. The Working Group on the Rights of Indigenous Populations / Communities in Africa was particularly concerned about the extent to which the "closure of markets in indigenous areas" affects livelihoods and "restrictions on mobility ... hamper their pastoral activities"; see "Press release on the impact of the COVID-19 virus on indigenous populations / communities in Africa" (23 April 2020, African Commission), available at: <https://www.achpr. org/pressrelease/detail?id=493> (last accessed 2 January 2021).

67 General Comment No 5, para 19.

68 Kampala Convention, art 10. For further discussion, see generally $\mathrm{R}$ Adeola Development-Induced Displacement and Human Rights in Africa: The Kampala Convention (2021, Routledge).

69 R Adeola "The Kampala Convention and the right not to be arbitrarily displaced" (2018) 59 Forced Migration Review 15.

70 UN Guiding Principles on Internal Displacement (1998), principle 7(3)(c). 
In the context of armed conflict, restrictions on the right to free movement and residence may be warranted to ensure the safety of the civilian population or for military necessity. However, where populations are moved due to these conditions, "all feasible measures" must be taken "to ensure that the civilians concerned are received under satisfactory conditions of shelter, hygiene, health, safety and nutrition, and that family members are not separated". ${ }^{71}$ This provision draws on the pointed guidance of article 17 of Additional Protocol II relating to the "prohibition of forced movement of civilians". ${ }^{72}$ Overall, displaced persons must be ensured "the right to voluntary return in safety to their homes or places of habitual residence as soon as the reasons for their displacement cease to exist". ${ }^{73}$ This is integral to the process of realizing durable solutions, as displaced persons may either choose to return to their homes, reintegrate locally or resettle elsewhere. ${ }^{74}$ The Kampala Convention is emphatic on choice, given that sustainability can only be achieved where a decision on a durable solution is reached with the participation of affected persons to ensure that they are both engaged and empowered in the process.

General Comment No 5 explicitly provides for state obligations in respect of actions by the state's executive, legislative and judicial arms. ${ }^{75}$ Setting out clearly the obligations of various arms of government draws on the need for explicit provisions for what the various arms of government are required to do in the furtherance of the right to freedom of movement and residence. The responsibilities of these arms are defined across three dimensions: respect, protect and fulfil. In the furtherance of respecting the right to freedom of movement and residence, the executive arm of government is required to ensure non-interference by public officials with the right in a manner that is at variance with international legal standards. ${ }^{76}$ On the responsibility to protect the right, the executive is required to ensure that violations by non-state actors are prevented, investigated and prosecuted. ${ }^{77}$ On promoting the right to freedom of movement and residence, the executive is required to ensure that public officials are adequately trained on relevant international legal standards relating to the right to freedom of movement and residence. In fulfilling this right, the executive is to "take measures that enable" the realization of the right to free movement and residence. ${ }^{78}$ The legislature is explicitly mandated to ensure that laws and policies are advanced in the furtherance of

71 General Comment No 5, para 21.

72 Protocol Additional to the Geneva Conventions of 12 August 1949 and Relating to the Protection of Victims of Non-International Armed Conflict (Additional Protocol II) (8 June 1977), art 17.

73 General Comment No 5, para 23.

74 The Kampala Convention, art 11.

75 General Comment No 5, paras 24-39.

76 Id, paras 26-31.

77 Id, para 28.

78 Id, para 30. 
the right to freedom of movement and residence. ${ }^{79}$ In protecting this right, the legislature is required to ensure that laws are adopted to further the accountability of non-state actors. ${ }^{80}$ While in promoting and fulfilling the right, the legislature is required to support debates on the realization of the right and adopt laws that enhance an environment in which the right will thrive. ${ }^{81}$ For its part, the judiciary "as custodian for the right to freedom of movement and residence" is to ensure that the right is duly interpreted in accordance with international standards. ${ }^{82}$ Consequently, it should refrain from decisions that are arbitrary, ensure that non-state actors are accountable for their actions and foster the fulfilment of the right through judicial review processes and writs or orders compelling public officials to carry out their responsibilities in the realization of the right. ${ }^{83}$

In explicitly providing for the responsibility of states for actions by non-state actors, General Comment No 5 reinforces the due diligence obligation of states under international human rights law. ${ }^{84}$ This obligation requires states to ensure that measures are taken "to prevent infringements, investigate allegations, prosecute perpetrators and punish violations by non-state actors". ${ }^{85}$ Actors recognized in this context include business enterprises, armed groups and private individuals. ${ }^{86}$ General Comment No 5 recognizes specific categories whose protection is imperative in view of the existence of international standards on the protection of these groups. ${ }^{87}$ Explicit recognition is given to 12 groups: "internally displaced persons, asylum seekers, refugees, returnees, migrant workers, women, children, nomadic populations, human rights defenders, older persons, persons with disabilities and persons living with HIV". 88 The rationale for including these groups, in addition to the fact that there are explicit normative frameworks for these categories, is that the vulnerability of these persons may be heightened where specific protection measures are not established. For instance, with respect to refugees, it was important to emphasize "efficient and quick processing of documentation", given that failure to provide this may affect the exercise of this right and access to services. ${ }^{89}$

Given the centrality of accessing justice and ensuring adequate remediation, General Comment No 5 further includes a specific section on accessing justice and remedies, explicitly providing that states must ensure a remedy in a

$\begin{array}{ll}79 & \text { Id, paras 32-35. } \\ 80 & \text { Id, para } 33 . \\ 81 & \text { Id, para 35. } \\ 82 & \text { Id, paras 36-39. } \\ 83 & \text { Id, para 39. } \\ 84 & \text { Id, paras 40-45. } \\ 85 & \text { Id, para 40. } \\ 86 & \text { Id, paras 43-45. } \\ 87 & \text { Id, paras 46-58. } \\ 88 & \text { Id, para 46. } \\ 89 & \text { Id, para } 49 .\end{array}$


"timely manner before an accessible competent tribunal or any other authority designated by law". ${ }^{90}$ States are also required to "provide legal aid and other forms of legal assistance to persons who seek to enforce their right to freedom of movement or residence". ${ }^{91}$ Given the importance of ensuring that the right to freedom of movement and residence is construed expansively, General Comment No 5 accentuates the need for the right to be interpreted broadly. ${ }^{92}$ In this way, General Comment No 5 reinforces an earlier position of the African Commission in General Comment No 3 on the Right to Life. ${ }^{93}$ General Comment No 5 further emphasizes reporting under article 62 of the African Charter, requiring states to ensure that they provide "details on relevant laws that have been adopted in order to give effect to the rights to freedom of movement and residence". ${ }^{94}$

Taking a holistic view of General Comment No 5, at its core it defines the regional position on freedom of movement and residence, expounding on the content of this provision and reflecting on movement in various contexts and with reference to different categories of persons, including IDPs and refugees. Notably, it presents an analysis of the right to freedom of movement and persons, moving beyond the conventional discourse of this issue from a focus on intra-regional movement to specific movement within state territories. Although it is often assumed that this form of movement is without impediments, in practice there are numerous concerns demonstrating that this is not always the case. In fact, given that this form of movement has largely been overlooked, it is often the case that it is treated from a security-based lens rather than a rights-based approach. General Comment No 5 presents significant guidance that could be used to sensitize state actors on adopting a rights-based approach to movement within their borders, particularly actors in the security sector including the police and civil protection units.

Moreover, General Comment No 5 offers a prism through which to conceptualize protection imperatives in specific contexts, such as in situations of armed conflicts, disasters and development projects. Understanding what freedom of movement and residence means in this context provides a basis on which to examine critically the extent to which such obligations are met where these circumstances arise. Moreover, it offers a basis for understanding how states should protect various categories of persons in the context of freedom of movement and residence in view of existing human rights obligations under treaties that articulate the protection of these groups.

By not making the right to freedom of movement and residence dependent on the legality of presence within a state, General Comment No 5 has broader

90 Id, para 59.

91 Ibid.

92 Id, paras 60-61.

93 See General Comment No 3 on the African Charter on Human and Peoples' Rights: The Right to Life (Article 4) (2015).

94 General Comment No 5, para 62. 
implications for the politics of movement. General Comment No 5 puts a check on the narrative that regularity of movement should be a critical factor for the enjoyment of the right to freedom of movement and residence. That this right is not predicated on the legality of an individual's presence in a state reinforces the pertinence of prohibiting arbitrary detention or indiscriminate restrictions on mobility.

The contribution of General Comment No 5 to international human rights law is that it seeks to provide comprehensive guidance on freedom of movement within state borders. As earlier observed, the Human Rights Committee's General Comment No 27 on article 12 of the ICCPR presents guidance on free movement in its composite form. While this is an important document and a notable reflection on the right to free movement, General Comment No 27 only briefly discusses movement within state borders. However, the regional general comment provides a detailed reflection on movement within state borders and, as such, presents relevant guidance from which other regional institutions may draw inspiration in the development of guidance to states on the content of the internal dimension of the right to free movement and residence.

\section{THE SOFT LAW NATURE OF GENERAL COMMENTS}

Although the African Commission adopted its first general comment in 2012, embracing the practice of the UN treaty bodies, what a "general comment" entails, and their significance and legal status within the African human rights system, remain less explored. ${ }^{95}$ Article $38(1)$ of the Statute of the International Court of Justice does not explicitly refer to the nature of "general comments" within the international legal order. Being an assemblage of "views" of members of a human rights body, general comments fall outside the explicit purview of article 38(1). Clearly, they are not treaties. The question may, however, be put as to whether they may evolve into "customary international law", based on the requisite state practice and opinio juris [acceptance of a practice as sufficient to create legal obligations]. ${ }^{96}$

95 Works that examine some of the African Commission's general comments include: E Durojaye "General comment of the African Commission on Human and Peoples' Rights: A source of norms and standard setting on sexual and reproductive health and rights" in O Shyllon (ed) The Model Law on Access to Information for Africa and Other Regional Instruments: Soft Law and Human Rights in Africa (2018, Pretoria University Law Press) 216 at 216-23; M Geldenhuys et al "The African Women's Protocol and HIV: Delineating the African Commission's General Comment on Article 14(1)(d) and (e) of the Protocol" (2014) 14 African Human Rights Law Journal 681; E Durojaye "The general comments on HIV adopted by the African Commission on Human and Peoples' Rights as a tool to advance the sexual and reproductive rights of women in Africa" (2014) 127 International Journal of Genecology \& Obstetrics 305.

96 M Olivier "The relevance of soft law as a source of international human rights" (2002) 35 Comparative E International Law Journal of Southern Africa 289 at 289. 
The African Commission's power to adopt general comments is unequivocal, being explicitly recognized as part of its role as interpreter of the African Charter: under article 45(2) of the African Charter, the African Commission has the power to "formulate and lay down principles and rules aimed at solving legal problems relating to human and peoples' rights and fundamental freedoms upon which African Governments may base their legislation". It is on this basis that the African Commission developed General Comment No 5 as an interpretive guide in the furtherance of the protection and promotion of human rights in Africa. In some other human rights systems, countries have questioned the legitimacy of treaty bodies as interpreters. For instance, Keller and Grover observe, with respect to the ICCPR, that "the United States and the United Kingdom in their submissions on draft General Comment No 33 (2008) rejected the idea that the [Human Rights] Committee is 'the' authoritative interpreter of the Covenant". ${ }^{97}$

This form of soft law, and soft law more generally, has flourished. One reason is that, because human rights provisions are generally vague and ambiguous, thereby potentially undermining effective treaty application, general comments step in to provide greater clarity. ${ }^{98}$ They should, however, not stray outside the normative reach of the founding treaty: general comments do not create new sets of obligations, they enhance the interpretation of existing norms. Alston underscores the fact that general comments are means through which a treaty body "distils its considered views on an issue which arises out of the provisions of the treaty whose implementation it supervises". ${ }^{99}$ Such processes are important, particularly in circumstances where a treaty is laden with "claw-back" provisions. The African Charter has several internal limitation (claw-back) clauses, prone to misinterpretation in the absence of clear guidance. A recurring claw-back provision is the reference to the "law" in the context of permissible restrictions to rights. Evidently, this creates ambiguity. Human rights (treaty) bodies develop general comments based on the jurisprudence that emerges from their work; ${ }^{100}$ in relation to the African Commission, this stems from the exercise of its

97 H Keller and L Grover "General comments of the Human Rights Committee and their legitimacy" in H Keller and G Ulfstein (eds) UN Human Rights Bodies: Law and Legitimacy (2012, Cambridge University Press) 116 at 133.

98 J Biegon "The incorporation of the thematic resolutions of the African Commission into the domestic laws of African countries" in Shyllon (ed) The Model Law on Access, above at note 95, 190 at 193; P Alston and R Goodman International Human Rights: The Successor to International Human Rights in Context (2013, Oxford University Press) at 792.

99 P Alston "The historical origins of the concept of 'general comments' in human rights law" in L Boisson de Chazournes and V Gowlland-Debbas (eds) The International Legal System in Quest of Equity and Universality Liber Amicorum Georges Abi-Saab (2001, Martinus Nijhoff Publishers) 763 at 763-64. See also P Gerber et al "General Comment 16 on State Obligations Regarding the Impact of Business Sector on Children's Rights: What is its standing, meaning and effect?" (2013) 14/1 Melbourne Journal of International Law 1 at 5 .

100 Keller and Grover “General comments”, above at note 97 at 117. 
protection mandate (the consideration of individual and interstate complaints) and from its promotional mandate (the examination of state reports, on-site country visits and investigations). ${ }^{101}$

Even if General Comment No 5 is not "law", this does not deprive it of the possibility of exerting significant moral and political force. As an interpretive guide, it systematizes and clarifies. Its persuasive force depends on a number of factors, including the subsequent use to which it is put by relevant actors.

\section{CONCLUSION}

Implementation is the ultimate expression of the relevance and value of treaties. To an important extent, effective implementation depends on clarity about the relevant state obligations. The adoption of general comments is part of a quest for greater clarity and better implementation. Over the last decade, general comments have become an important way through which the African Commission has sought to provide guidance on various charter provisions. In 2019, it added General Comment No 5, dealing with the right to free movement and residence of persons contained in article 12(1) of the African Charter. While the clarification of this obligation through General Comment No 5 is significant, it is important to emphasize that its value will largely depend on the extent to which it is used within national systems governing migration and mobility by lawyers, judges, academics, government officials, the media and other stakeholders. It is important that the African Commission continually engages states on the provisions of General Comment No 5 and leverages on the state reporting process as a means to interact more visibly and vocally with states on the subject. Moreover, it is important that General Comment No 5 is utilized in regional human rights jurisprudence. Overall, there should be significant engagement with civil society, in its broadest understanding, and with states at various levels of governance, to ensure that the right to free movement of persons is ensured in practice.

\section{CONFLICTS OF INTEREST}

None

101 D Long and R Murray "The role and use of soft law instruments in the African human rights system" in S Lagoutte et al (eds) Tracing the Roles of Soft Law in Human Rights (2016, Oxford University Press) 89 at 93. 